\title{
Home accidents in older people: role of primary health care team
}

\author{
Helen J Graham, Julia Firth
}

\begin{abstract}
Objectives-To determine the incidence and nature of unreported and reported home accidents in older people and to investigate associated environmental factors.
\end{abstract}

Design-Postal questionnaire requesting information on home accidents in the preceding month.

Setting-Inner London general practice.

Subjects-All registered patients aged over 65 years $(n=1662)$, of whom 120 were inappropriately registered and 1293 responded.

Main outcome measure-Circumstances and consequences of accidents in the home.

Results -108 accidents were recorded in 100 patients, giving a home accident rate of $84 / 1000$ patients, equivalent to an annual rate of $1002 / 1000$. 73 accidents were falls, and 83 were unreported. Of the 25 reported accidents, 19 were reported to general practice and six to accident and emergency departments $(5.6 \%$ of all events). Rates of home accidents increased with age and were higher in women than men $\left(79 / 819 v 29 / 474 ; \chi^{2}=4.5, \mathrm{df}=1\right.$, $\mathbf{p}<0.05$ ).

Conclusions - The incidence of home accidents in people aged over 65 years was high but few events were reported to medical services. General practice provided the main contact for patients who reported home accidents, and primary care workers have important opportunities for advising elderly patients on home accident prevention. Improved publicity on home safety targeted at older people and their carers would support the primary health care team in this role.

\section{Introduction}

Older people have the highest rate of fatal home accidents, and those aged over 75 years suffer the highest mortality. ${ }^{1}$ Falls account for most reported home accidents in this age group, and these may be complicated by injury and loss of confidence and functional ability. ${ }^{23}$ The rising incidence of hip fractures among elderly people ${ }^{4}$ and the consequent increased occupancy of orthopaedic beds ${ }^{5}$ is a cause for concern. As the proportion of elderly people in the population rises injury rates are expected to increase further.

Most studies of home accidents are based on populations consulting hospitals and general practice. ${ }^{26-8}$ Little information is available on unreported home accidents. If education on home safety is to be relevant it should be based on all home accidents. ${ }^{9}$ We investigated the incidence of unreported and reported home accidents in older people and determined their circumstances and consequences.

\section{Subjects and methods}

The study was undertaken in a group practice of eight principals in south east London. On 31 October
1989 we sent a postal questionnaire to all registered patients aged over 65 years $(n=1662)$, accounting for $9.7 \%$ of the 17140 patients included on the age-sex register on 1 October 1989 . The questionnaire invited patients, or carers on their behalf, to describe personal accidents, falls, or injuries which they had experienced in their homes or gardens, or when visiting others in October 1989 and to return the questionnaire within seven days. We limited the request for information to one month to minimise recall bias associated with memory impairment in older people. October was chosen because the weather and daylight hours promote a moderate degree of activity at home but it is not a main holiday period. The questionnaire was based on the World Health Organisation accident classification, ${ }^{10}$ and also asked whether patients lived alone; whether they were housebound and used mobility aids; and what type of accommodation they had.

To improve the response rate the primary health care team and wardens of sheltered housing were asked to identify patients who had had home accidents in the study period and to complete a questionnaire on their behalf if they had not responded. Hospital discharge summaries and accident and emergency department reports were screened for events. Patients and carers who had contact with the primary health care team within four weeks of the mailing were reminded to return completed questionnaires. Non-responders were not sent reminders as a delay would have adversely affected recall. The medical records of 100 consecutive non-responders were checked to identify inactive patients and those who had consulted with home accidents during the study.

Patients who indicated that they had had an accident were telephoned by HG for confirmation and, with their consent, were visited at home by one of us within 28 days. We used a standard questionnaire based on the home accident surveillance system ${ }^{8}$ to obtain the following information: the type of accident; whether injury occurred; outcome, including source of help if sought and whether referred to medical services; location of the accident in the home; and environmental hazards which may have contributed. The annual home accident rate was estimated.

\section{Results}

We received completed questionnaires from 1293 of the 1662 patients aged over 65 years. After correcting the age-sex register by removing 120 patients known to have died or moved away, 1542 patients were eligible for the study. The response rate was $84 \%$ with no significant difference between sexes (474/568 men $819 / 974$ women).

One hundred patients $(6.5 \%$ of the population at risk; $7 \cdot 7 \%$ of respondents) reported 108 home accidents in October 1989. Of these, 102 occurred in patients own homes and six in other homes. Six patients reported two accidents; one reported three; and one
Correspondence to:

$B M \mathcal{F}$ 1992;305:30-2 
demented patient with frequent undifferentiated falls was classified as having had one accident. One patient agreed to a telephone interview but refused a visit.

The incidence of home accidents increased with age: 43 of $686(6.3 \%)$ patients aged $65-74,44$ of $510(8.6 \%)$ aged $75-84$, and 13 of $97(13 \cdot 4 \%)$ aged over 85 had accidents. Women, who made up $63 \%$ of the study population, had a higher incidence of accidents than men; there were 79 accidents in 819 women compared with 29 accidents in 474 men $\left(\chi^{2}=4.5, \mathrm{df}=1, \mathrm{p}<0.05\right)$.

Of a sample of 100 consecutive non-responders, 47 may have been inaccurately registered as they either

TABLE I-Management and outcome of home accidents in elderly people

\begin{tabular}{|c|c|c|}
\hline Source of help & $\begin{array}{c}\text { Total No } \\
\text { of accidents } \\
(n=108)\end{array}$ & $\begin{array}{l}\text { No injured } \\
(\mathrm{n}=83)\end{array}$ \\
\hline Unreported to medical care & 83 & 60 \\
\hline Coped alone & 64 & 48 \\
\hline Help from relative or neighbour & 17 & 10 \\
\hline Advice from community pharmacist & 2 & 2 \\
\hline Reported to medical care & 25 & 23 \\
\hline General practice & 19 & 17 \\
\hline Accident and emergency department & 3 & 3 \\
\hline Admission to hospital & 3 & 3 \\
\hline
\end{tabular}

TABLE II -Classification of home accidents in elderly people, whether injury occurred, and whether reported to medical services

\begin{tabular}{|c|c|c|c|c|}
\hline \multirow{2}{*}{$\begin{array}{l}\text { Type of accident } \\
\text { Falls }\end{array}$} & \multirow{2}{*}{$\begin{array}{c}\begin{array}{c}\text { No of accidents } \\
(n=108)\end{array} \\
73\end{array}$} & \multirow{2}{*}{$\frac{\begin{array}{c}\text { No injured } \\
(n=83)\end{array}}{49}$} & \multicolumn{2}{|c|}{$\begin{array}{l}\text { No reported to medical services } \\
\qquad(n=25)\end{array}$} \\
\hline & & & & 19 \\
\hline Trip & 27 & 20 & 11 & $\begin{array}{l}\text { (General practitioner } 8 \text {, } \\
\text { accident and emergency } \\
2 \text {, inpatient }{ }^{\star} 1 \text { ) }\end{array}$ \\
\hline Slip & 17 & 13 & 2 & (General practitioner 2) \\
\hline Unsteadiness & 13 & 7 & 3 & $\begin{array}{c}\text { (General practitioner } 1 \text {, } \\
\text { accident and emergency } \\
1 \text {, inpatient }{ }^{\star} 1 \text { ) }\end{array}$ \\
\hline $\begin{array}{l}\text { Blackout or syncope } \\
\text { Fall from height }\end{array}$ & $\begin{array}{l}8 \\
4\end{array}$ & $\begin{array}{l}5 \\
2\end{array}$ & 2 & (General practitioner 2) \\
\hline Unexplained & 4 & 2 & 1 & $\left(\right.$ Inpatient $\left.{ }^{\star} 1\right)$ \\
\hline Other accidents: & 35 & 34 & & 6 \\
\hline Cuts from utensils, tools, or obstacles & 13 & 13 & 1 & (General practitioner $\mathbf{1})$ \\
\hline Knocks against stationary objects & 7 & 7 & 1 & (General practitioner 1 ) \\
\hline Struck by moving objects & 5 & 5 & 1 & (General practitioner 1 ) \\
\hline Insect or animal bite & 5 & 5 & 2 & (General practitioner 2) \\
\hline Burn or scald & 4 & 4 & 1 & (General practitioner 1 ) \\
\hline Choking & 1 & & & \\
\hline
\end{tabular}

^Admitted after reporting to accident and emergency department.

TABLE III - Reported and unreported home accidents which resulted in injury

\begin{tabular}{lcc}
\hline Injury & $\begin{array}{c}\text { Unreported } \\
(\mathrm{n}=60)\end{array}$ & $\begin{array}{c}\text { Reported } \\
(\mathrm{n}=23)\end{array}$ \\
\hline Contusion, swelling, sprain & 38 & 11 \\
Laceration or other wound & 16 & 5 \\
Burn or scald & 4 & 1 \\
Fracture & 1 & 5 \\
Choking & 1 & 1 \\
Concussion & & \\
\hline
\end{tabular}

TABLE IV-Location of home accident in elderly people

\begin{tabular}{|c|c|}
\hline Place & $\begin{array}{c}\text { No of } \\
\text { accidents } \\
(n=108)\end{array}$ \\
\hline $\begin{array}{l}\text { Indoors } \\
\text { Kitchen } \\
\text { Living or dining } \\
\text { room } \\
\text { Stairs } \\
\text { Entrance, threshold, } \\
\text { or porch } \\
\text { Bedroom } \\
\text { Hall or lobby } \\
\text { Bathroom, toilet } \\
\text { Outdoors } \\
\text { Garden, patio, } \\
\text { or yard } \\
\text { Garage, garden shed } \\
\text { Steps } \\
\text { Unclassified }\end{array}$ & \begin{tabular}{l}
$24^{80}$ \\
19 \\
11 \\
\\
8 \\
7 \\
7 \\
4 \\
\multicolumn{2}{c}{24} \\
17 \\
4 \\
3 \\
4
\end{tabular} \\
\hline
\end{tabular}

TABLE V-Activity of elderly patients at time of accident

\begin{tabular}{lccc}
\hline Activity & $\begin{array}{c}\text { Total } \\
(\mathbf{n}=108)\end{array}$ & $\begin{array}{c}\text { Falls } \\
(\mathbf{n}=73)\end{array}$ & $\begin{array}{c}\text { Other accidents } \\
(\mathbf{n}=35)\end{array}$ \\
\hline Household duties & 36 & 18 & 18 \\
Moving about house & 27 & 24 & 3 \\
Self care & 12 & 8 & 4 \\
Gardening & 12 & 8 & 4 \\
Walking in garden & 10 & 10 & \\
Do it yourself or hobbies & 6 & 1 & 5 \\
Unclassified & 5 & 4 & 1 \\
\hline
\end{tabular}

immobilisation from the injury (two of bronchopneumonia, one of cardiac failure), and five patients had fractures (three ribs, one scaphoid, and one tibia).

The home accident rate for one month for 1293 patients aged over 65 years in the corrected population at risk was $84 / 1000$ patients. Unreported home accidents accounted for $64 / 1000$ and accidents reported to medical services for $19 / 1000(15 / 1000$ to general practice; $5 / 1000$ to hospital). The estimated annual home accident rate based on these figures was $1002 /$ 1000 patients, with $770 / 1000$ unreported and $232 / 1000$ reported to medical services $(176 / 1000$ to general practice; $56 / 1000$ to hospital). The incidence of falls in one month was $56 / 1000$ with an estimated annual rate of $677 / 1000$

\section{HOME ENVIRONMENT}

Fifty eight accidents occurred in houses, 41 in flats, two in bungalows, and seven in sheltered housing units. Of the 100 patients who had accidents, 54 lived alone, 20 were housebound, and 33 used mobility aids. Accidents were more common in high activity areas such as the kitchen in which $24 .(22 \%)$ accidents occurred often during meal preparation (tables IV and V).

\section{Discussion}

Our estimated annual home accident rate of $1002 /$ 1000 patients, of which falls accounted for $677 / 1000$, suggests that most people aged over 65 can expect to have a home accident each year, and over half will experience a fall. Most home accidents and falls were not reported to medical services, and of those that were, most were reported to general practice rather than to accident and emergency departments. Although our figures include multiple events in accident prone patients they indicate a serious and widespread community problem in older people, and a consequent heavy burden for health care workers.

Previous studies have reported wide variations in home accident rates in elderly people. The home accident surveillance system estimated an annual rate treated at hospital of 20/1000 patients at age 65 years increasing to $90 / 1000$ with advancing age. ${ }^{.1}$ The general household survey found that $8 \%$ of older people had reported a home accident to general practice or hospital in the preceding three months, equivalent to an annual rate of 320/1000. ${ }^{7}$ A genera practice study undertaken 25 years ago on pensioners identified numerous unreported accidents and estimated the annual home accident rate at 196/1000, of which $17 / 1000$ were reported to general practice and $8 / 1000$ to hospital. Our higher rate (1002/1000 patients, of which $176 / 1000$ were reported to general practice and $56 / 1000$ to hospital) may be explained by more sensitive patient recall in a shorter study period, the use of a larger and more accurate population sample, and a recent increase in the numbers of very elderly people.

Surprisingly few serious injuries were recorded with fracture and mortality rates of $5 \%$ and $3 \%$ respectively. Only a quarter of the patients who described an injury as a result of their accident sought
Falls accounted for 73 of the 108 accidents (table II). Falls were more often reported to medical care (19/73, $26 \%$ ) than other accidents $(6 / 35,17 \%)$. The six patients who reported to hospital and 13 of the 19 who reported to general practice had fallen. Three patients died after 
medical care. Indeed, accident and emergency departments managed only six patients. Although most injuries were minor, many disrupted everyday activities, causing reduced mobility, loss of self confidence, and increased dependency on carers.

\section{CAUSES AND PREVENTION}

The causes of home accidents and falls in elderly people are complex. ${ }^{12}$ We had difficulty attributing an event to any one factor. Most resulted from an interaction of environmental hazards, physical disability, and carelessness or excessive risk taking. The contribution of environmental factors has been emphasised recently. ${ }^{13}$ Potential hazards identified in our study included inadequate lighting of kitchen work areas, stairs, half landings, porches, entrances, and cellars; lack of support on stairways and in bathrooms, where handrails were needed; inconspicuous steps and sills which would have been more obvious if accentuated with white edges or reflective strips; excessive clutter and loose rugs in high activity areas such as kitchens and living rooms; chair and bed heights too low for safe transfer; and ill fitting footwear especially slippers.

As we found that general practice rather than hospitals provided most patient contact after home accidents, the primary health care team has a potentially important role in preventing home accidents in older people. The question is whether an education programme for the whole elderly population or specific targeting of selected patients would be more effective in reducing home accidents? Advice on avoiding accidents given in the community by occupational therapists and health visitors did not significantly reduce falls, or injuries resulting from falls, in prospective trials. ${ }^{14}$ is An opportunistic approach could include counselling of patients who report home accidents, disabled people, and very elderly people, whom we found to have the highest incidence of home accidents. General practitioners should evaluate the contributions of medication, poor mobility, and impaired vision in patients who report home accidents and take appropriate action, including referral of patients with unexplained falls. ${ }^{9}$ District nurses with training in health education can also help identify high risk patients.

Whatever the potential of the primary health care team in reducing home accidents in older people, prevention is mainly a social responsibility. ${ }^{13}$ Public education on home safety encourages the recognition of personal risk, the modification of behaviour, and the creation of safe environments, and this has been attempted by the media, manufacturers, consumer and voluntary agencies, environmental health departments, ${ }^{16}$ local police, and supermarkets. Improved availability of large print leaflets on home accident prevention, with safety checklists based on those developed by the Royal Society for the Prevention of Accidents, ${ }^{17}$ would complement advice given in general $\mathrm{W}$ practice. Older people and their carers would benefit from a greater appreciation of accident prevention in the home, not only by the medical profession but also $\stackrel{\vec{S}}{\rightarrow}$ by all members of society.

We thank Professor Brian Livesley and members of the home and family safety committee of the Medical Commission $\overparen{\overparen{D}}$ on Accident Prevention for their advice. The study was supported by a grant from the Research for Ageing Trust.

1 Gloag D. Colloquium on strategies for accident prevention. A review of the present position. London: Medical Commission on Accident Prevention, 1987.

2 Gray B. Home accidents among older people. London: Royal Society for the Prevention of Accidents, 1966

3 Livesley B. "Funny tums", episodic loss of consciousness, and falls. The clinical neurology of old age. Chichester: John Wiley, 1989.

4 Finsen V. Improvements in general health among the elderly: a factor in the $\omega$ rising incidence of hip fractures? I Epidemiol Community Health 1988;42: or 200-3.

5 Office of Population Censuses and Surveys. Hospital in-patient enquiry, 1985. London: HMSO, 1987.

6 Lowry S. Accidents at home. BMJ 1990;300:104-6.

7 Office of Population Censuses and Surveys. General household survey 1981. W London: HMSO, 1983;6:138-9.

8 Department of Trade and Industry. Home and leisure accident research. Eleventh annual report home accident surveillance system: 1987 data. London: DTI, 1989.

9 Livesley B. Falls in older age. BMF 1984;289:568-9.

10 World Healh Organisation Regional A basic data set and guidelines for its use. Target 11. Geneva: WHO, 1988.

11 Department of Trade and Industry. Home and leisure accident research. Accidents to the elderly. London: DTI, 1986.

12 Askham J, Glucksman E, Owens P, Swift C, Tinker A, Yu G. A review of research on falls among elderly people. London: Age Concern Institute of Gerontology, 1990.

13 Department of Health. On the state of the public health for the year 1989. The annual report of the chief medical officer of the department of health. London: HMSO, 1990.

14 Campbell AJ, Borrie MJ, Spears GF, Jackson SL, Brown JS, Fitzgerald JL. Circumstances and consequences of falls experienced by a community population 70 years and over during a prospective study. Age Ageing $\overrightarrow{\bar{B}}$ 1990;19:136-41.

15 Vetter NJ, Lewis PA, Ford D. Can health visitors prevent fractures in elderly people? BMF 1992;304:888-90.

16 London Borough of Bromley. Report of national conference and workshops on home safery. Bromley: Environmental Services, 1990

17 Royal Society for the Prevention of Accidents. Safety of elderly people: a checklist for those providing care. Birmingham: ROSPA, 1989. (Leaflet HS229.)

(Accepted 4 June 1992)

\section{Is there a maximum safe dose of vitamin $C$ (ascorbic acid)?}

The question of safety of high doses of vitamin $\mathrm{C}$ remains controversial, as it has been for the past three decades at least. The daily amount needed by normal human adults to prevent or cure the deficiency disease, scurvy, is less than $10 \mathrm{mg}$ a day. Blood and tissue concentrations rise steeply over the range $20-100 \mathrm{mg}$ a day (depending on dose schedules and individual variations in economy), but for most people there are no overt adverse reactions to high doses until these reach at least several grams a day. The commonest adverse reaction at high intakes is bowel intolerance, mainfested as actue diarrhoea.

Because of the benefits of vitamin C, mainly as an antioxidant, in combating pro-oxidant damage from free radical and other oxidants in model systems, and in view of the epidemiological evidence linking relatively high intakes of foods rich in vitamin C (fruit and vegetables) to a relatively low risk of certain degenerative diseases in humans, some authorities believe that intakes above the range that is usually provided by the human diet may give protection against occasional destructive events and are therefore, on balance, beneficial. Others argue that these benefits remain unproved and that such high intakes carry an appreciable risk of toxic side effects - for example, those listed by Flodin ${ }^{1}$ - which may outweigh the possible benefits.

In a recent document on dietary supplements and health foods published by the Ministry of Agriculture, Fisheries, and Food and Department of Health a long term daily intake of vitamin $\mathrm{C}$ at or above $6 \mathrm{~g}$ was considered to be "undesirable." No upper limit was specified in the Department of Health's report Dietary Reference Values for Food Energy and Nutrients for the United Kingdom, although some possible risks were noted as being associated with daily intakes of grams. ${ }^{3}$ Research interest in this question is undoubtedly increasing, and new techniques of showing subtle tissue damage and the efficacy of protective agents such as vitamin $C$ are being assessed.-C J BATES, Dunn Nutrition Centre, Cambridge

1 Flodin NW. Micronutrient supplements: toxicity and drug interactions. Prog Food Nutr Sci 1990;14:277-331.

2 Ministry of Agriculture, Fisheries, and Food, Department of Health. Dietary supplements and health foods. London: Ministry of Agriculture, Fisheries, and Food and Department of Health, 1991:16.

3 Department of Health. Dietary reference values for food energy and nutrients for the United Kingdom. London: HMSO, 1991:121. (Report on health and social subjects 41 .) 